\title{
О ПРОБЛЕМАХ И ВОЗМОЖНОСТЯХ РАЗВИТИЯ КУРОРТА КАВКАЗСКИЕ МИНЕРАЛЬНЫЕ ВОДЫ
}

\section{(C) 2019 Хурмагов Ибрагим Алиевич}

кандидат экономических наук, доцент кафедры экономики и антимонопольного регулирования Российская академия народного хозяйства и государственной службы при Президенте Российской Федерации, Северо-Кавказский институт-филиал, Россия, Пятигорск

Email: Ibragim-kn@mail.ru

В статье акцентируется внимание на внешних и внутренних факторах, влияющих на дальнейшее развитие рекреационного региона, обладающего уникальными природными ресурсами оздоровительного свойства, концентрируется цель и задачи мероприятий по внедрению инновационных форм и методов в управление стратегией развития курорта.

Ключевые слова: рекреация, природные ресурсы, оздоровление, санаторно-курортная сфера, доктрина, стратегия, перспективы.

В поле зрения Правительства РФ постоянно находится вопрос о повышении эффективности функционирования внутренних курортов, к числу которых относятся и Кавказские Минеральные Воды (КМВ), обладающие уникальными природными ресурсами оздоровительного свойства. Функционирование курорта происходит в соответствии с программойразвития приоритетных секторов экономики страны «Туристско-рекреационный кластер», цель которой - повышение привлекательности и эффективности работы туристско-рекреационного комплекса на данной территории, доведение его уровня до мировых стандартов.Данный вопрос весьма актуален, т.к. в последнее десятилетие россияне отдают предпочтение зарубежным курортам и местам летнего отдыха, отмечая более высокий уровень обслуживания и предоставления услуг за ту же или даже меньшую стоимость, чем в России. Так в чём же причина сложившейся ситуации? Почему наши курорты, в частности санаторно-курортный и туристский комплекс KMB, не могут соперничать с зарубежными аналогами (Баден-Баден, Карловы Вары и другие). Обсуждаются и принимаются доктрины, стратегии развития курорта, выделяются значительные бюджетные ассигнования, но отдыхающих становится всё меньше и меньше. Особенно в зимний период, когда персонал здравниц переводится на неполный рабочий день, штат медицинского персонала сокращается, производственные мощности используютсячастично. Понятно, что последствия незагруженности здравниц самые непредсказуемые - теряются грамотные, ценные кадры, приходят в негодность основные производственные фонды, искажается внешний облик городов-курортов. Недостаток финансирования отражается и на природоохранной деятельности, постепенной потере целебных свойств рекреационных ресурсов, например, грязевого озера Тамбукан, которое постепенно опресняется. Многие источники минеральной воды закрыты, водопроводные системы и бюветы пришли в негодность. Так почему же маркетологи не проводят сравнение привлекательных преимуществ для отдыхающих российских и зарубежных курортов? Чем же они так манят россиян, которые не считаются ни с перелетом, ни со временем, уезжая на отдых в другие страны?

Исследование данного вопроса, больного для курорта КМВ, привело к следующим результатам.

Считаем, что необходим кардинальный перелом в сознании наших людей, работающих в сфере курорта и туризма, перестройка подхода в целом. Прежде всего, нужно изменить организацию питания отдыхающих. Тот же «шведский стол», широта выбора блюд будут способствовать предпочтениям гостей. Ну и, конечно же, качество продуктов и блюд значительно отстает от существующих норм. Причина тому - слабый внутренний и внешний контроль, «повязанность» должностных лиц, это приводит к наличию «несунов», они до сих пор не ликвидированы, процветают и многие местные жители живут за счет покупки по заниженным ценам мяса, масла и других продуктов, которые не до- 
ложили в порции отдыхающим или заменили их менее калорийными те, кто имеет непосредственный доступ к продовольственному складу санатория, профилактория или дома отдыха. Существуют же в мире рычаги воздействия на менталитет людей? Конечно. Но у нас этим никто не занимается, боясь потерять свой «кусок масла». И сколько бы ни принималось решений и постановлений, дело не сдвинется с места.Начинать следует с изменения психологии работников. Оказывается, не так много нужно сделать, чтобы привлечь отдыхающих - организовать качественное и разнообразное питание, достойное обслуживание, добиться привлекательного вида санатория и прилегающей территории, обеспечить доброе, внимательное отношение обслуживающего персонала к гостям. А ключ к этой перестройке - повышение заработной платы персонала. И источник уже есть - курортный сбор. Голодный человек, целыйдень обслуживающий гостей за мизерную плату, будет искать какой-то дополнительный доход.

И еще одна проблема, стоящая между здравницей и отдыхающим в последние годы - навязываете платных услуг. Безусловно, платные, дополнительные услуги, прием узкими специалистами, полные обследования, нужны и важны. Но, заплатив за путевку весьма высокую цену, внеся курортный сбор, оказывается, что за эти деньги человек получает совсем мало процедур, вместо, например, 10-12 ванн, как раньше, сейчас назначают только 5-6 ванн. А остальное - пожалуйста, за отдельную плату. Фактические расходы на лечение и отдых увеличиваются в 2-3 и более раз. Более того, санатории рекомендуют всем приобретать процедуры, которые, в лучшем случае, бесполезны, но могут и нанести вред здоровью, например, введение в вену озона (озонотерапия). Однако существует негласный план «зарабатывания» денег на платных услугах, поэтому и процветает такая негуманная практика, и нет уверенности, что она имеет место в зарубежных здравницах.

Хотя есть и другие примеры, свидетельствующие о том, что и у нас возможно достичь такого высокого уровня развития курортного дела.

Таким объектом в Пятигорске является санаторий «Пятигорский нарзан», который возглавляет Герой Ставропольского края Татьяна Арсентьевна Чумакова. Не нужно ехать за рубеж - здесь даже лучше. Строжайший контроль и учет, работники вышколены, работают за до- стойную оплату, им совершенно невыгодно чтото унести из санатория. Планерки проводит сама руководитель дважды в день - утром и вечером. Многие работники переведены на поденную работу - по результатам дня. Прямо к санаторию подведен радон, чего нет в других санаториях, отдыхающим которых приходится выезжать за пределы здравниц в радоновую лечебницу. Современный, оборудованный дизайнерами обеденный зал, с фарфоровой и хрустальной посудой, серебром и красивыми скатертями. Современная мебель. А блюда лучше, чем в ресторане, причем, по заказам, из свежайших натуральных продуктов. Территория ухожена, во дворе беседка, бассейн, кругом цветы, зеленые «слоны» и др. По вечерам - скрипка и лучшие певцы развлекают отдыхающих во дворе. Круглый год все места заполнены. Хотя путевки гораздо дороже, чем в другие санатории. Налицо пример работы курортного объекта, каким он должен быть.

Таким образом, если бы и другие здравницы нашли способы перестроиться на новые методы работы, то курортникам нечего было бы искать за пределами России.

Территория Кавказских Минеральных Вод, как курорт, является перспективным направлением региона, планирующим превращение его всовременный высокоэффективный туристско-рекреационный и туристско-спортивныйцентр, обеспечивающий возможности для удовлетворения потребностей российских изарубежных граждан в туристско-рекреационных услугах и увеличивающий притокиностранных инвестиций (например, китайских), а также способствующий увеличению количества рабочих мест.Предполагается, что конечной целью преобразований на рекреационной территории будет создание более привлекательного курорта с эффективнойэкономикой и развитой инфраструктурой.

Анализируя содержание федеральных программ развития «Юг России», «Развитиесанаторно-курортного и туристского комплекса Кавказских Минеральных Вод до 2020 года», Государственной программы Российской Федерации «Развитие Северо-Кавказского федерального округа», а также Стратегии развития внутреннего и въездного туризма в Северо-Кавказском федеральном округе (СКФО) до 2035 года, думается, что в настоящее время уже есть все основания, чтобы приступать к реализа- 
ции намеченных мероприятий развития КМВ как курорта мировогокласса, а не только как горноклиматического курорта.В соответствии с указанной Стратегией, число мест размещения (гостиниц, отелей, хостелов, гостевых домов) в СКФО составит к 2024 году 99 тыс., к 2030 году - 153 тыс., к 2035 году - 271 тыс. Объем инвестиций в основной капитал проектов по строительству гостиниц и отелей должен вырасти до 3 млрд. рублей к 2024 году, 9 млрд.- в 2030 и 16 млрд.- к 2035 году. Предполагается также, что реализация мероприятий стратегии положительно отразится на росте турпотока и увеличении количества жителей округа, трудоустроенных в сфере туризма. Если туристический поток на Северный Кавказ по итогам 2018 года составил 1,5 млн. человек, то, по оценкам экспертов, этот показатель может быть увеличен к 2024 году до 4,5 млн. чел. [1]

В числе основных мероприятий по развитию Кавказских Минеральных Вод - использование возможностей старого и создание нового научно-технического и кадровогопотенциала; привлечение и эффективное использованиеинвестиционных ресурсов, включая внешние источники, привлекаемые за счетмежрегионального взаимодействия; сочетание государственного регулирования ирыночного механизма хозяйствования, с использованием программно-целевого планирования развитиятуристско-рекреационного комплекса; выбор системного подхода к проблемамэкономического развития, мониторинга и адаптации субъектов к изменяющимсяусловиям хозяйствования; социальная направленность развития курорта в интересах региона.

Наряду с внешними факторами, немаловажное значение имеет и оценка внутренних факторов, к числу которых относится, к примеру, достигнутый уровень качества жизни населения курортного региона, состояние иперспективы развития местного социально-экономического потенциала, предоставленные санаторно-курортные услуги в расчете на одного отдыхающего и т.п. В соответствии с Паспортом подпрограммы «Комплексное развитие инфраструктуры и благоустройство Кавказских Минеральных Вод», целью ее станет создание объектов социальной инфраструктуры и повышение комфортности городской среды, необходимой для улучшения качества жизни населения. Общий объем бюджетных ассигнований федерального бюджета на 2019-2021 годы составитоколо 4,2 млрд. руб. А ответственный исполнитель - Министерство РФ по делам Северного Кавказа [2].

В ходе анализа проблем и факторов, существующих в туристско-рекреационной отрасли ипрепятствующих инвестиционно-инновационной деятельности, выявилась необходимостьпроведения некоторых изменений, как на федеральном, так и на местном уровнях, а именно: совершенствование законодательной базы в санаторно-курортной сфере; разработка и внедрение инновационныхмероприятий в курортной медицине; создание благоприятных экономических условий для инвестиционной деятельности в области обновления основных фондов курорта; осуществление государственной информационной поддержки.

На субрегиональном уровне управления необходима реализация следующихнаправлений: проведение инвентаризации и сертификации санаторно-курортных предприятий и формирование на этой основе баз данных о ресурсном потенциалекурорта КMB; инвентаризация сложившихся институциональных условий для развития туризма в Северо-Кавказском регионе (Домбай, Архыз, Приэльбрусье), реализация мероприятий по продвижениюрекреационного продукта на внутренний и внешний рынки; создание действенногомногоаспектного механизма обеспечения безопасности туристов и рекреационныхобъектов в регионе, в том числе, их страхование, как один из основных способов защиты имущественных интересов страхователей при наступлении страховых случаев; модернизация сложившейся в регионе системы подготовки и переподготовки кадров, повышение их квалификации, винтересах преодоления дефицита в специалистах туристско-рекреационной сферы.

На локальном уровне, в пределах муниципальных образований, основные усилиядолжны быть направлены на стимулирование создания новых туристских объектовразмещения и модернизацию традиционных курортных комплексов. Для этогонеобходимо сочетание общих усилий по улучшению инвестиционного климата нарекреационной территории с адресным государственным воздействием на узловыепроблемные ситуации и потенциальные «точки роста».

Думается, в ближайшее время обострится конкурентная борьба на рынке рекреационных 
услуг, чтопотребует выхода на сцену менеджеров нового поколения, серьезного изменения ворганизации и управлении, прежде всего, крупными объектами размещения, формирования гостиничных цепочек, системы центров реабилитации, встроенных всистему здравоохранения.

Особое внимание в настоящее время следует уделить природоохранной деятельности на территории курорта КМВ. Уже есть некоторый опыт внедрениярентных платежей в сфере природопользования, однако он носят пока незавершенный характер. Имеется методика определения рентной составляющей от использования курортно-рекреационных территорий, основанная на синтезе современных научных взглядов и теоретико-методических подходов.

Таким образом, повышение роли региональной и муниципальной компоненты в социально-экономическом развитии страны, потребует от глав территорий не просто определения приоритетов развития, а разработки адаптированной рыночной модели развития. При таком подходе становится актуальнойнеобходимостью применение моделей, методик и мер по стимулированию экспортатуристско-рекреационных услуг местной экономики и, соответственно, создание натерритории КМВ - курорта мирового класса [3].

Для выбора модели управления рекреационной территорией важно провести предваритель- нооценку ее экспортного потенциала. Для этого вероятно использование методики оценкирегиона с точки зрения: конкурентоспособности территории; специализации хозяйственного комплекса территории; потенциала кластеризации; состояния и прогнозирования развития экспортного потенциала; развития и проведения сравнительного анализаэкспортного потенциала регионов; расчета эффективности экспортной деятельности; комплексной оценки экспортного потенциала. С этой связи, на основе методик, необходимо оценить сильные и слабые стороны уникальной рекреационной территории дляэкспорта туристско-рекреационных услуг, а также оценить место территории в структуре экспортастраны в настоящее время, учесть влияние внешних и внутренних факторов и выявитьперспективы развития курорта. В результате такого анализа, появляется выбор наиболее адекватной длясовременных условий хозяйствования модели управления сферой туристско-рекреационных услуг уникальной территории.

В настоящее время анализ и оценка состояния и возможностей расширения и улучшения качества услуг на территории Кавказских Минеральных Вод имеет исключительнобольшое значение для повышения конкурентоспособности туристско-рекреационныхуслуг субрегиона.

\section{Библиографический список}

1. Стратегии развития внутреннего и въездного туризма в Северо-Кавказском федеральном округе (СКФО) до 2035 года. Электронный доступ: pinfo@krskfo.ru

2. Государственная программа Российской Федерации «Развитие Северо-Кавказского федерального округа», утв. постановлением Правительства РФ от 15 апреля 2014 года № 309(в редакции, введенной в действиес 20 февраля 2019 года). Электронный доступ: pinfo@krskfo.ru

3. www.kmv-kurort.ru/ Сайт КМВ-курорт. 